\title{
In hal t:
}

Geschichte der klassischen Literatur.

Ankiindigung - . . . . . . . . . . . . . . . 3

Vorerinnerung . . . . . . . . . . . . . . . 5

Algemeine Übersicht des gegenwäirtigen Zustandes der Deutschen Literatur . . . . . . . . . . 16

\section{(i riechische Poesie.}

Virerinnerung . . . . . . . . . . . . . . . 95

Griechische Sprache . . . . . . . . . . . . 97

Hemerisches Epos . . . . . . . . . . . . . . 110

Ilias . . . . . . . . . . . . . . . . 126

Odysser. . . . . . . . . . . . . . . . . 145

Homeridische Hymnen. . . . . . . . . . . . . 163

Hesiodisches Epos . . . . . . . . . . . . . . 164

Mirtleres Epos . . . . . . . . . . . . . . . 168

Virgils Aeneide . . . . . . . . . . . . . . . . 171

Epopöe der Römer nach Vilgil und der Neueren. . . 199

Henriade... . . . . . . . . . . 213

Messiade . . . . . . . . . . . . . . . . 216

Das scherzhafte Heldengediclit . . . . . . . . . 222

Lyrische Poesie der Alten. . . . . . . . . . . 231

Jamben und Elegien. . . . . . . . . . . . . 245

Melische Jichtung . . . . . . . . . . . . . . 250

Chorische Dichtung . . . . . . . . . . . . 256

Pindar . . . . . . . . . . . . 257

Ilitlyrambes . . . . . . . . . . . . . . . . . 259

Boraz . . . . . . . . . . . . . . . . . . $\mathbf{2 6 0}$

Molerne Nachbildungen der Classischen Iyrik . . . 263 
Geschichte der Elegie . . . . . . . . . . . . 265

Heroide . . . . . . . . . . . . . . . . . 284

Vom Lehrgedicht . . . . . . . . . . . . . . 291

Über die dramatische Poevie der Griechen . . . . 317

Literatur der Griechische Tragödie . . . . . . . . 333

Aescbylus . . . . . . . . . . . . . . . . 334

Sophoties . . . . . . . . . . . . . . . . 340

Euripides . . . . . . . . . . . . . . . . . 351

Parallele . . . . . . . . . . . . . . . . . 360

Dio Choephoren dea Aeachylua . . . . . . . . . . 360

Elektra des Sophokles . . . . . . . . . . . 363

Elektro des Euripides. . . . . . . . . . . . 366

Die alte Komödie . . . . . . . . . . . . . . 37

\section{A nhang.}

Die neuere Komödie . . . . . . . . . . . . . 383

Mimen . . . . . . . . . . . . . . . . . . 355

Idylle . . . . . . . . . . . . . . . . . . 394

Satire . . . . . . . . . . . . . . . 395 